\title{
人間ドック長期継続高齢受診者の成績検討 (体重の変化と検査成績との関連)
}

鈴木 豊明 成田登喜子 清水 敏朗

\section{目 的}

人間ドック長期継続高齢受診者を対象に体重の変化 が諸検査成績に及ぼ影響, 成人病予防との関連につ

いて検討した。

\section{対象と方法}

若年から，65歳以上まで経過を追った 204 例につ き, 体重の変化別に減少 $5 \mathrm{~kg}$ を越えた A 群, 減少が 1 $\mathrm{kg} \sim 5 \mathrm{~kg}$ 末満 B 群, 変化なかった C 群, 増加 $1 \mathrm{~kg} \sim 5$ $\mathrm{kg}$ 末満 D 群, 増加 $5 \mathrm{~kg}$ を越えた $\mathrm{E}$ 群の 5 群につき高 血圧・心電図異常・腎・肝・ DM - TC・TrG・UA $\cdot \mathrm{KW}$ の 9 項目の検査成績の変動を比較検討した。肥満度は Body mass index 20〜24 を正常, 26.5 以上を肥満と し，検査成績は規定の判定基準によった。

\section{成 績}

$\mathrm{A}$ 群 37, B 群 20, C 群 83, D 群 36, E 群 28 例別の 前後における各検査項目の異常頻度より高齢時におけ る新たな異常の発現率を求めると, もっとも低值は上 記項目別に多少の相違はあるが $7 \%, 10 \%, 10 \%, 10 \%$, $5 \%, 6 \%, 8 \%, 5 \%, 14 \%$ と体重変化の少ない C 群で, 体重減少の多い $\mathrm{B}, \mathrm{A}$ 群で緩やかに, 増加の多い $\mathrm{D}$, E 群で，29\%，32\%，19\%，36\%，27\%，43\%，29\%， $20 \%, 18 \%$ と急峻な上昇を示す。つまり, C を底辺とし て「J」または「U」型を描く。即ち検査値の変動に は肥満度はもとより体重の変動が大きく影響し, 体重 の変動は成人病のリスクを増し, 健康にマイナスに働 <。

次に, 肥満群 55 例, 正常体重群 93 例の 2 群につい て体重の変動別に同様の検討を行った。中年時（前） 高齢時（後）の成績の異常率は腎を除きいずれも肥満 群で高かったが, 変化率は肝, TC, UA, KW で肥満
群に高く, 有意の差を認めたが, 他の項目では殆ど差 が認められなかった。体重変動別 5 群の間では肥満・ 正常両群とも体重の変動の少ないC 群を低值とする $\lceil\mathrm{J} 」 又 は 「 \mathrm{U} 」$ 字型を描き, 高血圧, UA で肥満の影 響が認められるが，他は肥満よりむしろ体重の変動の 影響が大きい。

肥満者では一時的に減量できても，何らかの契機て 再び体重が増加し, 減量増加を繰り返す, いわゆる「ヨ ーヨー現象」について検討した。ヨーヨー現象陽性者 は対象と比べ心電図異常, 腎, TC, TrG, KW の異常 の発生が多かった。

体重の変動と健康に関する報告は多い。体重の変動 の中で内臓脂肪の減少が問題視され最近 CT による内 蔵脂肪量の測定が行われ, 又, Aaron R Folsom は, $\mathrm{W} / \mathrm{H}$ 比をルーチンのサーベランスやリスクモニター の一部として測定すべきと説いているがそれに触れ た。

\section{まとめ}

人間ドック長期継続高齢受診者を対象に体重の変化 の諸検査成績に及ほす影響について検討した。

体重変化別に 5 群にわけ, 中年時と高齢時とを前後 を比較，高血圧・心電図異常・腎・肝・DM 高脂血・ $\mathrm{KW}$ の検査成績の変動は体重変化の少ない群を最低 とする J 又はU 字型を描き，これらの年代にあって は，肥満そのもの影響はもちろんであるがそれ以上に 体重の変化が以後の成績に影響する。

高齢者にあっては肥満を避けるよう努めることも大 切であるが, 多少の肥満があっても肥満そのものより も寧ろ中年時の従来の体重維持に努めることが健康維 持に重要であることを強調したい。

\footnotetext{
Studies of Results of Long-Repeated Advanced Age Examinees in Ningen-Dokku (The Relation Between Change of Body-Weight and Examination-Results) 東京警察病院保健検診センター
} 